Dicle University Journal of Engineering (DUJE)

web: http://dergipark.gov.tr/dumf

Derleme Makalesi / Review Article

\title{
Ulaştırmada Türel Seçim ve Toplu Ulaştırma Hizmet Parametreleri Bağlamında Bir Derleme
}

\section{A Review on the Context of Modal Choice on Transportation and Mass Transport Service Parameters}

\author{
Mehmet Fatih Altan ${ }^{1 *}$, Mehmet Çağrı Kızıltaş², Yunus Emre Ayözen ${ }^{3}$ \\ ${ }^{1}$ İstanbul Aydin Üniversitesi, İnşaat Mühendisliği Bölümü, İstanbul, mehmetaltan@aydin.edu.tr \\ ${ }^{2}$ İstanbul Ticaret Üniversitesi, İnșaat Mühendisliği Bölümü, İstanbul, mckiziltas@ticaret.edu.tr \\ ${ }^{3}$ Devlet Hava Meydanları Işsletmesi Genel Müdürlüğü, Ankara, yunusemre.ayozen@dhmi.gov.tr
}

\begin{tabular}{|c|c|}
\hline MAKALE BİLGİLERİ & ÖZET \\
\hline Makale geçmişi: & \multirow{6}{*}{$\begin{array}{l}\text { Türler arası dengeli dağılım ve entegrasyonun sağlanmasıyla trafik güvenliğinin gereken düzeye çıkarılması } \\
\text { mümkün olabilecektir. Bunun için, toplu taşımanın bütün ulaştırma türlerinde gerekli ve yeterli alternatiflerle, üst } \\
\text { düzey hizmet parametreleriyle sunumu önemli olacaktır. Toplu taşımanın kullanıcılar tarafından tercih edilir hale } \\
\text { getirilmesi için ihtiyaçla örtüşüyor olması (arz-talep), tüketim kültürü ile eşgüdümlü bir yönetişimle yürütülmesi, } \\
\text { hizmet parametrelerinin düzeyi (hız, güvenlik, maliyet, güvenilirlik vb) ve son teknolojiyle donatılmış olması } \\
\text { gereklidir. Tüketim kültürünün yönetişimi noktasında, Hollanda'da bir işadamının bisikletle ulaşımını } \\
\text { gerçekleştirmesinin söz konusu ülkedeki alışkanlıklarca olağan karşılanmaktadır. Ama gerek Hollanda ve gerekse } \\
\text { de Japonya ve benzeri ülkelerin ulaştırma sistemlerinin sunduğu hizmet parametrelerinin de tercih noktasında } \\
\text { kullanıcıları daha esnek kıldığı da söylenmelidir. Bu anlamda; planlama, entegrasyon ve farklı disiplinler arası } \\
\text { eşgüdümün önemi de ortadadır. Bu bağlamda, ulaştırma sistemini teknolojik gelişmeler ve mevcut gereksinimler } \\
\text { dâhilinde iyileştirirken hizmet parametreleri ile ilgili dengeli ve genel bir iyileştirmenin şartları oluşturulmak } \\
\text { durumundadır. Yapılan kapsamlı anket sonucunda ulaşı tercihinin yaş, gelir grubu ve eğitim düzeyinden ciddi } \\
\text { anlamda etkilendiği görülmüştür. Özellikle İstanbul gibi dinamik kentlerde klasik analizlerin dişına çıkılması } \\
\text { gerekmektedir. }\end{array}$} \\
\hline Geliș: 19 Aralık 2019 & \\
\hline Düzeltme: 13 Eylül 2020 & \\
\hline Kabul: 15 Eylül 2020 & \\
\hline Anahtar kelimeler: & \\
\hline $\begin{array}{l}\text { Türler arası entegrasyon, kent içi } \\
\text { ulaşım, Marmaray, kent içi raylı } \\
\text { sistemler, toplu ulaşım }\end{array}$ & \\
\hline
\end{tabular}

Doi: 10.24012/dumf.661453

\begin{tabular}{|c|c|}
\hline ARTICLE INFO & ABSTRACT \\
\hline $\begin{array}{l}\text { Article history: } \\
\text { Received: } 19 \text { December } 2020 \\
\text { Revised: } 13 \text { September } 2020 \\
\text { Accepted: } 15 \text { September } 2020\end{array}$ & $\begin{array}{l}\text { Transportation has an increasing importance and attention because of the development trends on various } \\
\text { disciplines and especially very rapidly improvement of innovative technologies. Cities are largening. Urban areas } \\
\text { are growing as a parameter of population and immigration on developing countries, developed countries and even } \\
\text { on undeveloped countries too in all over the World. Urbanization is a phenomena for } 21^{\text {st }} \text { century. On futures } \\
\text { mobility; sustainability, urbanization and digitalization will be on a very strategical point. }\end{array}$ \\
\hline $\begin{array}{l}\text { Keywords: } \\
\text { High speed railways, intermodal } \\
\text { integration, modal distribution, } \\
\text { transportation system }\end{array}$ & $\begin{array}{l}\text { On this context intermodal integration and balanced modal distribution are going to become very significant and } \\
\text { determinant for trnsport and related disciplines. Especially innovative technologies are going to support } \\
\text { transportation system for solution of traffic safety problems, traffic congestion problems and related issues. } \\
\text { Beside all of these; as a part of sustainability and efficiency of mentioned system, enhancing the usage rates and } \\
\text { improving of mass transport will be a focus point for the solution of the problems and providing an effective } \\
\text { system. In this paper, at the field survey it has seen that transport choice is deeply affected by age, income and } \\
\text { education. Epscially it is a necessity to exceeding conventional analysis for dynamic cities like Istanbul. }\end{array}$ \\
\hline
\end{tabular}

* Sorumlu yazar / Correspondence

Mehmet Fatih ALTAN

$\bowtie$ mehmetaltan@ticaret.edu.tr 


\section{Giriş}

Ulaştırma ülkelerin ekonomik gelişmişliklerinde etkileyen ve etkilenen bir konumdadır. Verimli çalışan bir ulaştırma sistemiyle sosyal ve ekonomik yönden avantajlar geliştirilebilmekte olup konut, istihdam, sanayi ve iş alanları daha erişilebilir kılınmaktadır. Günümüzde küreselleşme, teknik ve ekonomik gelişmeler ulaştırma sistemlerini yenilikçi bir anlayışla ele almayı gerekli hale getirmiştir. Teknolojide kat edilen mesafe talebi hem arttırmış hem çeşitlendirmiş ve hem de yenilemiş olup hizmet parametreleri, konfor ve kapasitede bir büyümeyi de beraberinde getirmiştir [1]. Ülkemizde son on yılda kat edilen mesafe ile karayolu ulaştırma türünün dengesiz ağırlığı özellikle kent içi raylı sistem yatırımlarıyla nispeten kırılmıştır ancak yeterli iyileşme ve özel otomobil sahipliğindeki artışın dengelenmesi için daha kapsamlı yaklaşımlar söz konusu olmalıdır. Bu kapsam; türler arası entegrasyondan şehir planlamasına, disiplinler ars1 koordinasyondan mevzuat iyileştirmelerine ve tüketim kültürünün yönetişimine kadar bir dizi tedbiri ihtiva etmektedir. İstanbul'da Asya'dan Avrupa'ya geçişlere bakıldiğında bunun \% 81'inin köprülerden gerçekleştiği ve bunun da önemli oranının özel otomobillerce oluşturulduğu görülmektedir [2].

Daha büyük fotoğrafa bakılır ise yolculuk yapanların sadece \%24'ünü taşıyan özel araçlar boğaz geçişlerinde \%90'ın üzerinde bir paya sahiptir. Öte yandan yolcuların \%37'sinden fazlasını taşıyan lastik tekerlekli toplu ulaştırma araçları ise boğaz geçişlerinin sadece \%10'unu işgal etmektedirler. Boğaz köprülerindeki trafik tıkanıklıklarının sebeplerine daha detaylı bakıldığında; özel otomobil sahipliği oranlarındaki sürekli artışın yanı sıra bu araçlardaki yolcu ortalamalarının da 1,2-1,5 düzeylerinde olması nedeniyle çok sayıda araçla kısıtlı sayıda yolcu geçişinin sağlandığı da anlaş1lmaktadır [2]. Bu noktada, köprülerden insanlardan ziyade araçların geçtiği çıkarımı da yapılabilir. Bütün bunlardan hareketle toplu taşıma odaklı yaklaşımların önemi daha da iyi anlaşılmaktadır. Aşağıda Şekil 1'de 1996-2006 yılları arasında İstanbul'un kent içi ulaşımındaki türel dağılım değişimi görülmektedir. Şekil 1'de görüldüğü üzere, kent içi ulaşımda türel dağılımdaki farklılaşma esas olarak 1996 yılı sonrası dönemde gerçekleşmiş olup, özel otomobiller ve servis araçlarında önemli oranda bir artış gerçekleşmiştir. Bu çerçevede Kent dahilinde son 14 yılda gerçekleştirilen metro ve genel olarak raylı system hat yatırımları hummalı bir çalışmanın sonucu olarak söz konusu resmin en azından müspet yönde biraz değişmesine destek sağlamıştır [3].

İstanbul gibi kentler için toplu ulaştırmada türel tercihte muhtelif birçok sayıda belirleyici unsur söz konusu olmaktadir. İstanbul'un sosyo ekonomik yapısının yanı sıra tarihi karakteri ve engebeli arazi şeklinin de bunun üzerinde çeşitli etkileri bulunmaktadır. Kentte motorlu taşıt sahipliliği günden güne hızla artmaktadır. Diğer taraftan halen nüfusun önemli bir kısmının hiç aracı bulunmamaktadır. Diğer taraftan ise eğitimli ve genç nüfus hızla artar iken bu da çevreci ve sürdürülebilir kaygıların içselleşmesini deteklemektedir. Yine Türkiye'nin yerli otomobil sektöründe istenilen yerde olmaması ve petrolü dışarıdan ithal etmesi İstanbul ulaşımına da yansıyan önemli zorluklardır.

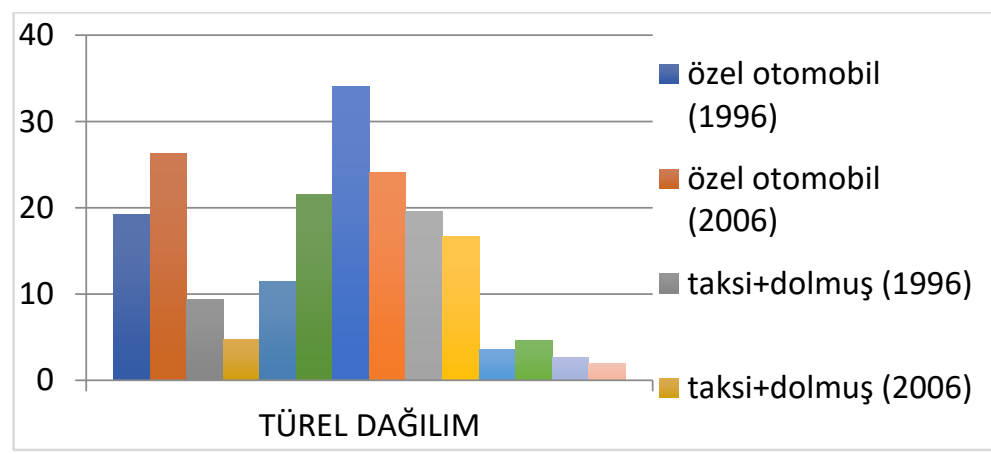

Şekil 1: 1996-2006 Dönemi Ístanbul Kent içi Ulaşımında Türel Dağılım [3]

\section{Materyal ve Yöntem}

İstanbul'da ulaştırma değerlerine bakıldığında toplu ulaşımın kent için önemi daha iyi 
anlaşılmakta olup toplu ulaşımın kullanımının arttırılmasının aciliyeti ortaya çıkmakta ve hali hazırda sistemin toplu ulaşım kullanım oranlarının arttırılmasına da elverişli olduğu görülmektedir. Bunun için de; toplu ulaşım ile bireysel ulaşım arası entegrasyon, toplu ulaşım içerisinde bilet entegrasyonu, fiziksel entegrasyon, mekânsal entegrasyon, filo entegrasyonu gibi bir dizi başlık ortaya çıkmaktadır [4]. Kentte trafik tıkanıklığının katlanılabilir düzeylere çekilmesinde ve ulaştırma sisteminin daha verimli ve etkin çalışmasında kent içi raylı sistem yatırımlarının önemli bir rolü bulunmaktadır. İstanbul'da 2004'ten günümüze önemli oranda metro ve hafif raylı sistem hattı inşası devam etmekte olup 17 Ağustos 2012 yılı itibariyle Kadıköy-Kartal Metro hattı işletime alınmış, takibinde de bu hattın devamı olarak Kartal-Pendik-Tavşantepe metro hattı da 10 Ekim 2016 itibariyle açılmış olup böylelikle İstanbul' un güney aksı boyunca, iki havaalanını birbirine bağlayan (Atatürk Havaalanı ve Sabiha Gökçen Havaalanı) kesintisiz raylı sistem ulaşımının önü açılmıştır. 2010'da İstanbul'da verilen yolculuk değerlerinde türel dağılımda karayolu ulaştırma türünün \%78,4'lük ağırlığı olup 2014'te $\% 67,7$ 'ye, 2018'de \%50,7'ye, 2023'te \%26,5'a düşmesi öngörülmektedir. 29 Ekim 2013 itibariyle kısmen açılışı yapılan Marmaray'ın 2014 itibariyle türel dağılımda \%7,4; 2018' de $\% 7,9 ; 2023$ 'te ise $\% 5,7$ 'lik paya ulaşması öngörülmektedir. İstanbul'daki trafik tıkanıklığı sorununun katlanılabilir noktaya geriletilmesinde bir diğer ana belirleyici de kent içi raylı sistem hatlarının yaygınlaştırılmasıdır [5].

Şekil 2'de ise kent içi raylı sistemlerin karayolu trafik tıkanıklığını hafifletici etkisi bağlamında otoyol trafik tıkanıklığının düzey ve maliyetleri verilmektedir. Kent içi raylı sistem hatlarından ise yaygın yatırım alanı olarak metro hatlarının yapılması gerekliliği ve bu hatların birbiriyle entegre bir şekilde gerçekleştirilmesi gerekliliği ortaya çıkmaktadır. İstanbul'da 10 Eylül 2007 itibariyle işletime alınmış olan, ilk ve tek örnek olarak işletilen metrobüs hattı (BRT), dünyada Uzakdoğu ve Latin Amerika'da yaygınlığı olan bir sistemdir, günlük ortalama 800.000 kişilik taşıma gerçekleştirmekte ve tam kapasite olarak çalışmaktadır [6].

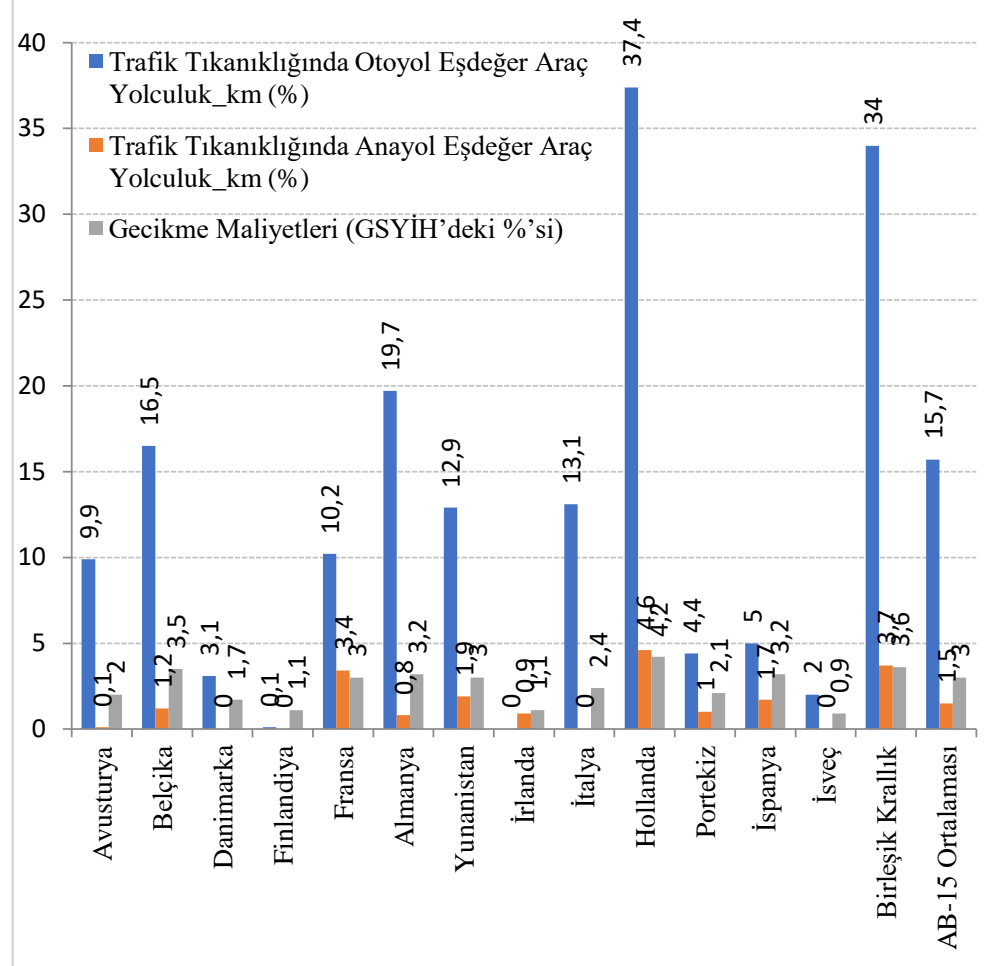

\section{Şekil 2: Karayolu Trafik Tıkanıklığı Düzeyleri ve Gecikme Maliyetleri [5].}

Boğaz aşan bir hat olarak metrobüs mevcutta 37'si Avrupa yakasında, 7'si Anadolu yakasında olmak üzere 44 duraktan meydana gelmekte ve şehri ana ulaşım aksında doğu-batı yönünde birbirine bağlamaktadır. Metrobüs, süre ve maliyet yönünden kayda değer kazanımlar sağlamakta olup, kapasitesinin üzerinde çalışması nedeniyle konfor ve güvenlik parametreleri yönünden yeterli olamamakta ve şehre ikinci bir metrobüs hattı, mevcut metrobüs hattının uzatılması, mevcut metrobüs hattının altyapı ve işletim koşullarının iyileştirilmesi ve mevcut metrobüs hattına paralel metro hattı gibi senaryolar değerlendirilmektedir. 
Ulaştırma yatırımları hem nitelik ve hem de nicelik bakımından büyüdüğünde, nüfus açısından yoğun olan kentlerde arazi kullanım değerleri de ön plana çıkmaktadır. Şekil 3'de dünyanın muhtelif bölgelerinde nüfus yoğunluğu yüksek kentlerdeki ulaştırmaya ayrılan arazi oranları gösterilmektedir.

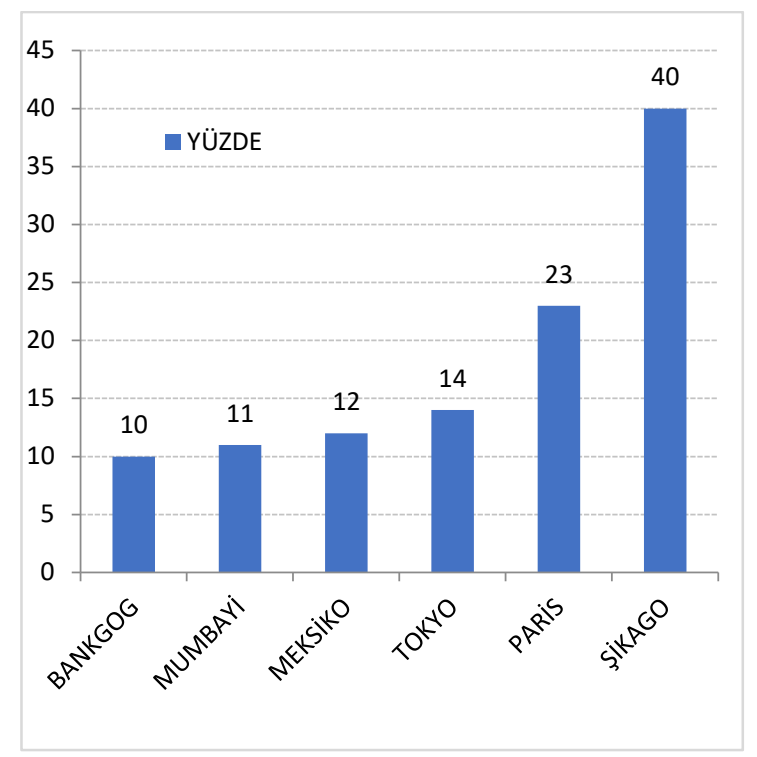

Şekil 3: Ülkelere Göre Kent Merkezlerinde Ulaştırmaya Ayrılan Kentsel Alan Dağglımı [7].

\section{İstanbul Kent İçi Ulaşım Anketi}

$\mathrm{Bu}$ söz konusu anket Mehmet Çağrı Kızıltaş tarafından 2016-2017 yıllarında çevrimiçi ortamda bine yakın katılımcı ile İstanbul Toplu Ulaşımı merkezli olarak gerçekleştirilmiştir.

- Anket 16-63 yaş arası 850 kişiyle gerçekleştirilmiş olup yaş ortalaması 24'tür.

- Katılımciların \%59'u erkek \%41'i bayandir.

- Ankete katılanlar; kitap satıc1s1, muhasebeci, belediye çalışanı, banka personeli, memur, pdr (psikolojik danışmanlık ve rehberlik) uzmanı, firın sahibi, proje idarecisi, diş doktoru, hukukçu, tekniker, mühendis, milli eğitim çalışanı, mühendis, diyetisyen, akademisyen, teknisyen, güvenlik personeli, uçak pilotu, gemi kaptanı, tüccar, laboratuar personeli, sağlık çalışanı, peysaj mimarı, hizmet sektörü çalışanı, ağır iş çalışanı, makine idarecisi, matbaacı, yazar, fotoğrafçı, gayrimenkul uzmanı, ev hanımı, mimar, turizm personeli, kimyacı, kamu çalışanı, hekim, mali müşavir, iş adamı, din görevlisi, arşiv uzmanı, kargo elemanı, operator, berber, kasiyer ve serbest meslek gibi birçok meslek kolundandır. Ayrıca ön lisans, lisansüstü ve lisans gibi muhtelif decerelere sahip çok sayıda öğrence katılmıştır.

- Katılımcıların eğitimi düzeyi ülke ve il genelinin üzerindedir. Yaklaşık 3'te 2'si lisans ve/ya ön lisans derecesini haizdir. Yüksek lisans dereceliler katıldığında bu oran \%70'in üzerini bulmaktadır.

- Katılımcilar yoğun olarak, Anadolu yakasındaki Kartal, Pendik, Üsküdar, Beykoz, Ümraniye, Çekmeköy, Maltepe, Tuzla, Sultanbeyli, Kadıköy ve Ataşehir ilçelerinde oturur iken Avrupa yakasında da Avcılar, Sarıyer, Fatih, Sultangazi, Esenler, Esenyurt, Kağıthane, Güngören, Zeytinburnu, Başakşehir, Silivri, Beylikdüzü, Beyoğlu, Gaziosmanpaşa, Eyüp, Beşiktaş, Arnavutköy, Bayrampaşa, Bakkırköy, Küçükçekmece, Şişli ve Bağcılar ilçelerinde ikamet etmektedir.

- Yine katılımcıların yoğun bir şekilde iş ve/ya okul amaçlı olarak Pendik, Fatih, Bağcilar, Ümraniye, Arnavutköy, Üsküdar, Tuzla, Zeytinburnu, Beyoğlu, Şişli, Kağıthane, Sarıyer, Bakırköy, Zeytinburnu, Başakşsehir, Eyüp, Büyükçekmece, Sancaktepe, Küükçekmece, Esenyurt, Ataşehir, Bayrampaşa, Bahçelievler, Beylikdüzü, Esenler, Beşiktaş, Beykoz, Kartal ve Gziosmanpaşa'ya yolculuk ettikleri görülmektedir.

Ankete iştirak edenlerin 3'te 2'si Avrupa yakasnda ve yaklaşık 3'te 1'i ise Anadolu yakasında oturmaktadır. Ankete katılanların $\% 3,6$ 's1 her gün Avrupa'dan Anadolu'ya ve $\% 4,2$ 'si ise her gün tersine Anadolu'dan Avrupa'ya iş-okul amaçlı seyahat yapmaktadır. Yani atılımcıların toplamda $\% 7,8$ 'i hergün bir 
yakadan diğerine yolculuk etmektedir. Buradan hareketle ankete katılanların çok büyük bir kısmının kendi oturduğu yakada oturduğu (veya çalıştığı) ve dolayısı ile de boğaz köprüsü trafiğine doğrudan maruz kalmadğı açıkça görülmektedir. Bu kişilerin toplam katılımcılar içerisindeki paylarına bakılır ise Anadolu yakasında ev-iş yolculuklarını yapanlar toplam ankete katılanların \%29,0'unu oluşturur iken söz konusu oran Avrupa yakası dahilinde ise \%63,2'yi bulmaktadır. Ankete katılanların oturdukları yakalar, İstanbul'un genel istihdam dağılımı ile örtüşmektedir. Yine bu verilenlerden anlaşılmaktadır ki İstanbul'un denizden uzaklaşan ve çok merkezli bir yapıya doğru ilerleyen bir kent olduğu yorumları isabetli görünmektedir. Ankete katılanların yaklaşık 3'te 1 'i ise $(\% 33,1)$ günlük ev-iş yolculuklarını güney aksta yani Marmaray'ın merkeziliğindeki güzergahta yapmaktadır. Bu hattın artık temel bileşeni Gebze-Halkalı İstanbul metrosudur [7].

\section{Uygulama ve Başarımlar}

Ankete katılanların yaklaşık 3'te 2'si toplu ulaştımayı her gün kullanmaktadır. Ankete katılanların \%8'i toplu ulaştırmayı günde 1 kereden fazla kullanır iken \%53'ü ise günde 1 kez kullanmaktadır. Anket katılımcılarının İstanbul'un ortalama eğitim düzeyinin üzerinde bir eğitim düzeyini haiz olduğu daha önce de belirtilmiştir. Söz konusu toplu ulaştırma kullanım düzeyleri de İstanbul ortalamsının üstündedir. Buradan hareketle de bunun sadece bir doğru orantı olmaktan kapsamlı ve çok yönlü tahlil edilmesi gerekli bir husus olduğunu da belirtmektet fayda vardır. Bu kapsamda; eğitim seviyesi yükseldikçe toplu taşıma kullanımında da doğru orantılı olacak bir şekilde her zaman artış olacağ1 söylenemez [8]. Ancak genel anlamda, anketten çıkan bu eğilim değerlendirilecek olursa, söz konusu artışın bir yönü eğitim seviyesine paralel olarak artan tüketici bilinçlenmesi ise diğer bir yönü ise ülkemizin sosyal bir gerçekliği olarak, uzun süreli eğitim hayatı içerisinde iken aynı zamanda da çalışma hayatında kayda değer bir pozisyonlarda bulunan önemli miktardaki bir kitlenin varlığıdır. Söz konusu kitle özellikle İstanbul, Ankara, İzmir ve mücavir şehirlerinde ciddi bir nüfus teşkil etmektedir. $\mathrm{Bu}$ nüfusun yıllık gelirleri ise halen k1sitlı düzeydedir. Dolayısı ile tüketim kültürlerini aynı zamanda zorunlu olarak da disipline etmek durumundadırlar. Her 3 katılımcıdan 1'i ağırlıklı olarak, toplu taşımayı haftada birkaç kez ya da ayda birkaç kez kullanırken bu dilimin büyük bölümünün ev-iş/okul yolculuklarında özel araç kullandığı ve dolayısıyla özel araç sahip olduğu çıkarımı kabaca yapılabilir. Ancak özel araç sahibi kitlenin zaman zaman toplu taşımayı tercih etme oranının son on y1llık süreçte ne yönde ve hangi ivmeyle değiştiği hususunun da ayrıca incelenmesi gerektiği düşünülmektedir. $\mathrm{Bu}$ kitle için ise son on yılda inişli çıkışlı ve değişken bir performanstan söz edilebilir. Zira söz konusu kitle geniş bir nüfus kesimini (İstanbul için, nüfusun yaklaşık yarısı) teşkil ettiğinden farklı farklı sosyal katmanlardan meydana gelmektedir. Ulaştırma ve erişilebilirlik imkânlarının arttığı bölgelerde, bilinçli tüketici olarak addedilebilecek kullanıcılar gün içi araç kullanım miktarları bağlamında toplu taşıma ve yaya ulaştırma türüne daha fazla teveccüh göstermektedir [9]. Yine; yakıt fiyatlarında artış ve trafikteki zaman kaybının maliyete olan yansımalarından ötürü de araç sahibi kitlenin bir bölümü zorunlu olarak gündelik hayatlarında toplu taşımaya daha fazla yer açmakta olup söz gelimi araçlarını ev-iş yolculuklarının haricindeki yolculuklarda kullanma yönelimi göstermektedirler. Ancak bu kisitların nispeten dışında kalan geniş bir kitle ise hem hemen her tür yolculuklarında ve de hemen her mesafede, gündelik hayatlarında araçlarına başvurmaya devam etmektedirler.

Ankete katılanların \%50'si ev-iş (okul) seyahatlerinde kent içi raylı sistemleri kullandıklarını belirtmişlerdir. Yine Marmaray'ı kullananlar ise \%18,5 çıkmjıştır. IETT ve ÖHO'ları (özel halk otobüsü) kullananlar 
toplamda \%58'in üzerindedir. $\mathrm{Bu}$ noktada \%42'den fazlası ise BRT'yi (metrobüs) kullanmaktdır. Nerede ise katılımcıların 3 'te 1 ' $i$ aynı seyahatler için minibus-dolmuşu kullandığını ifade eder iken deniz ulaşımının kullananlar ise \%11'in üstünde bir oranı Ayn değerler taksilerde \%10, özel araçlarda \%22,8 ve servis araçlarında da \%10,6 olarak gerçekleşmektedir. Buradan hareketle halkının çoğunluğunun kent içi raylı system yatırımlarının genelinden memnun olduğu ve yatırımların sürmesini beklediği, yatırımlar arttıkça kullanım kültürünün gelişeceği, Marmaray'a ilgi gösterdiği ve de eğer bu eğilim devam ederse de ulaştırma sisteminn daha da iyileşip trafik tıkanıklığının azalabileceğine inandığı sonuçlarına ulaşılabilirdir [10]. Tabi bu noktada Gebze-Halkalı İstanbul metrosunun işletim performansı da önemli ve belirleyici bir noktada olmaktadır. Bununla beraber ykit fiyatlarına ve kullanım alışkanlıklarına bağlı olarak aracını özellikle boğaz köprüsü aksı trafiğinden çeken bir kitlenin olduğu ve bunda da artış gözlemlendiği anlaşılmaktadır. Buradaki tek ana neden elbette ki tüketim kültüründeki nispi bilinçlemme değildir. Söz konusu etki; genele nazaran sinırlı bir etki olarak gerçekleşmektedir. Belki tek başına ulaştırma sisteminde türel dengeni değişimi ya da toplu taşımaya yönelim konusunda ciddi bir belirleyiciliği olmamaktadır. Fakat değişen kullanıcı ölçüleri ve hassasiyetlerinin yerel idari mekanizmalar tarafından sürekli ve güncel olarak ölçülmesi ve değerlendirilmesi ve hatta yönetilmesinin gerekliliği fikrini desteklemektedir. Deniz ulaştırmasına yapılan tercih İstanbul ortalamasından yüksektir ancak anketteki muhtelfi sorularla birlikte değerlendirme yapıldığında bu oranların kalıcı bir seçim olmayabileceği düşünülmektedir. İETT ve özel halk otobüslerine olan tercih halen ilk sirada yer alırken, bunun kismen zorunlu bir tercih (raylı sistem hatları yatırımlarının henüz artış aşamasında olması) olduğu kadar da - diğer anket sorularında daha açık görüleceği üzere kısmen de gerçekleştirilen iyileştirmeler olduğu (filo artışı, filo yenilenmesi, hat optimizasyonları, durak uygulamaları, diğer sistemlerle entegrasyondaki kısmi iyileşmeler) anlaşılmaktadır [11]. Ankete katılanlara hizmet parametrelerinden memnuniyet oranları da sorulmuştur. Verilen cevaplarda ise siklık ve güvenilirlik $\% 26$, maliyet $\% 23$ ve hzdan memnuniyet ise \%36 olarak çıkmıştır. Ayrık hatlarda (raylı sistemler) ya da özel şeritlerde (metrobüs) işletim imkanı, İstanbul'un genel trafik tıkanıklığına maruz kalmamayı beraberinde getirmektedir. $\mathrm{Bu}$ nedenle de söz konusu hatlarda $35 \mathrm{~km} /$ saat dolaylarındaki hızlar dahi ortalama İstanbul trafik akım hızlarına nazaran (15 km/saat) birçok güzergahta zamandan çok ciddi tasarrufları beraberinde getirmektedir. $\mathrm{Bu}$ da anket katılımcisı nezdinde 'yüksek hız' şeklinde yanılsamaalı bir alg1 birakmaktadır [12]. Ankete katılanlar konfor hizmet parametresinden memnun değildir, bu oran iştirak ednelerin \%30'unu teşkil etmekte olup söz konusu memnuniyetsizlik oranları sıklık-güvenilirlik için \%24,9 ve maliyetler (bilet fiyatı) için ise \%24,4'tür. Güvelikle ilgili memnuniyetizlik düzeyi $\% 13,8$ 'dir. Konfor ve güvenlik birlikte telakki edildiklerinde söz konusu değer \%44'lere ulaşmakta olup bu da İstanbul toplu ulaştırmasının en ivedi problemine işaret etmektedir. Söz konusu durum özellikle de metrobüslerde seyahat esnası ile muhtelif yerlerdeki metro ve metrobüs istasyonlarına erişim ile ilgili mevzu bahis olabilmektedir. Özellikle de İstanbul Büyükşehir Belediyesi'nin (IBBB) aldığ 1 güncel bir karar olarak metrobüs ve metroda 24 saat kesintisiz ulaşım, bu bağlamda da planlanıp düşünülmelidir [13]. Tabiki konfor ve güvenlik konularını hem taksiler ve hem de dolmuş ve minibüsler için de ayrı ayrı düşünülmesinde fayda vardır. Özellikle de minibüslerin artık kooperatif şeklinde bir kamu özel ortak iştirak şirketi bünyesinde toplanıp İstanbul Büyükşehir Belediyesi (İBB) ve T.C. Ulaştırma ve Altyapı Bakanlığı (UAB) bünyesindeki bir kurumun tarafindan denetlenen bir yapıyı haiz noktaya getirilmesinde de fayda ve aciliyet görünmektedir [13]. Ücret tarifesi 
konusunda memnun olanların oranı yüksektir ancak bir o kadar da memnun olmayan bulunmaktadır ancak konu İBB'nin son dönemdeki öğrenci ulaşımı indirim kararıyla birlikte düşünüldüğünde ortada duran ivme halihazıra olumlu yöne evrilebilir bir potansiyeldedir. Dakiklik konusu ise metro ve kentiçi raylı sistemler genel olarak yaygınlaştıkça memnuniyet yönüne evrilecek bir orta vadeli sürece bağlı olarak görünmektedir [14]. Mevcut tablodan; 3.köprünün kamuoyunda - bütün taraflarca - yeterince 'politik angajmanlardan sıyrılarak' tartışılamadığını açıkça ortaya koymaktadır. Her 5 katılımcıdan 2'si toplu taşımadan genel memnuniyetini 'iyi' olarak ifade etmiştir. Bu soruya 'normal' cevabını verenler $\% 28$, 'yetersiz-çok yetersiz' yaklaşık 1/3'tür [14].

\section{Sonuçlar ve Tartışma}

Kullanılan yol hacmi ve taşınan yolcuya göre yapılan değerlendirmelerde taşımacılık açısından toplu taşımanın özel araca kıyasla 30 katlara varan bir performansı söz konusudur [14]. Bu anlamda, toplu taşımanın sürekliliği ve tercih edilirliği açısından işletmecinin kazanımlarını muhafaza eden ve kullanıcıya da zamandan ve maliyetten kazanç sağlayan, yeterli konfor ve güvenlik parametrelerini sağlayan bir çerçevenin temin edilmiş olması önemlidir. Bu noktada, zirve saatlerde ticari hızın İstanbul genelinde ortalama olarak nispi bir düzeyde yükseltilebilmesi önemli kazanlar sağlayacak potansiyel de olup bu anlamda toplu taşımadan başlayarak özel şerit uygulamasının devreye alınması ile birlikte mevcut yol platformunun yeterli olduğu güzergâhlarda (yeterli orta orta kaldırım genişliği vb) hızlı otobüs tarzı uygulamalara başvurulması değerlendirilebilir [15].

İstanbul'daki trafik tıkanıklığı sorunuyla ilgili, başta metro olmak üzere LRT (hafif raylı tren), HRS (ağır raylı sistem), tramvay ve benzeri kent içi raylı sistem hatlarından faydalanılması önemli noktalardandır. İstanbul Büyükşehir Belediyesi, 2000'li yılların başından itibaren yaptığı kent içi raylı sistem yatırımlarıyla \%200'lere yaklaşan bir artış kaydetmiştir [15]. Ancak; İstanbul için hâlihazırdaki durum da yeterli değildir. 10 . Kalkınma Planı ve 11. Ulaştırma Denizcilik ve Haberleşme Şurası başta olmak üzere 2014, 2019 ve 2023 yıllarını kapsayan, İstanbul için nihai olarak $776 \mathrm{~km}$ hattı ihtiva eden kapsaml hedeflerin ortaya konulduğu görülmekte olup bu hedeflere ulaşılması için yerel yönetim (İstanbul Büyükşehir Belediyesi) ve hükümetin (T.C. Ulaştırma Denizcilik ve Haberleşme Bakanlığı) ciddi anlamda eşgüdüm, uyum ve koordinasyonu gerekmektedir [16].

Konfor, güvenlik, güvenirlik, hız, maliyet ve benzeri hizmet parametreleri dikkate alındığında, özellikle yeni yerleşmekte olan trendler bağlamında da, yolcuların kendi önceliklerini feragat edebilecekleri ve edemeyecekleri birçok değişken söz konusu olup bu durumun hizmet parametreleri için de aynen geçerli olduğu görülmektedir [17]. Örneğin bir boğaz köprüsü veya tünele koyulan geçiş ücretine, talebe etkisi muhtemel kullanıcı kitlesinin geliştirdiği tutum ve tavir, söz konusu kitlenin hangi parametreleri daha öncelediğini de açıklamaktadır. Söz gelimi yüksek maliyetli bir geçiş ücretine rağmen söz konusu ulaştırma yapısını kullanan kesimin, trafikte kaybedeceği zamanın parasal değeri, verdiği geçiş ücretinden yüksektir. Diğer taraftan yüksek geçiş ücreti nedeniyle söz konusu ulaştırma yapısını kullanmak yerine farklı bir güzergâhı ya da farklı bir ulaştırma türünü kullanan kitle için ise maliyet feragat edilemeyecek noktadaki bir hizmet parametresi iken, zamandan ve/veya konfordan belli ölçülerde feragat edilebilir. $\mathrm{Bu}$ bağlamda, İstanbul'da metrobüs kullanıcıları konfor ve güvenlikten feragat ederken, üst düzey bir zaman kazanc1 elde etmektedir. İstanbul'da boğaz köprüsü kullanıcılarının için ise zamanın parasal değer, ödedikleri köprü geçiş ücretinden daha yüksektir. İstanbul'da sürekli metro kullanıcıları, konfor ve erişilebilirlikten belli ölçülerde feragat etmeyi göze alabilirken hizmet parametrelerine 
olan hassasiyetlerinin hız, güvenilirlik ve sıklıkla ilgili olduğu anlaşılmaktadır [18].

İstanbul'da türler arası entegrasyon noktasında bilet entegrasyonunun büyük ölçüde sağlandığ ancak fiziksel entegrasyonun (filo bütünlügü) ve mekânsal entegrasyonun (aktarma merkezleri) henüz tam anlamıyla sağlanamadığı görülmekte olup türel dağılımda karayolu ulaştırma türünün ağırlığının halen tam olarak kırılamadığ anlaş1lmaktadır [19]. Bu durum; karayolu ulaştırma türünde özel otomobilin ciddi ağırlığ ile beraber okunduğunda Karayolu Trafik Güvenliği için başlı başına bir sorun teşkil etmekte ve konfor, güvenlik, seyahat süresi gibi hizmet parametrelerinin sağlanmasını da açıkça engellemektedir (T.C. Karayolları Genel Müdürlüğü [20]. Buradan da anlaşılacağı üzere bu yıl açılışı yapılan 3.Boğaz Köprüsü'nün, hat rehabilitasyon çalışmaları devam eden Marmaray'ın, bu yıl içerisinde açılacak olan Avrasya Tüneli'nin ve halihazırda inşaat yada planlama safhasında olan diğer bütün projelerin bu kapsam ve kayitlarla değerlendirilmesinde fayda vardır.

$\mathrm{Bu}$ anlamda; teknolojinin gelişimi, yatırımların yönlendirilmesi, şehirlerin gelişim stratejileri ve ulaştırma sistemlerinin iyileştirilerek geliştirilmesi 'insan odaklı' bir perspektifle görülmeli ve eyleme dökülmelidir.

\section{Teşekkür}

Bütün mesai arkadaşlarımıza teşekkürü bir borç biliriz.

\section{Kaynaklar}

[1] Ilıcalı M., Çatbaş N., Öngel A., Kızıltaş M.Ç., (2013) 'Multimodal Transportation Issues in Istanbul: A Case Study for Traffic Redistribution Due to Long Span Bridge Rehabilitation', Hong Kong,.

[2] Kızıltaş M.Ç., (2014) 'Ulaştırma Yatırımları ve Marmaray-1',

http://www.ulastirmadunyasi.com/index.php/2013/12/ulast irma-yatirimlari-ve-marmaray-1/ (24.04.2014).

[3] Kızıltaş M.Ç., (2014) 'Ulaştırma Yatırımları ve Marmaray-4', http://www.ulastirmadunyasi.com/index.php/2013/12/ulast irma-yatirimlari-ve-marmaray-4/ (24.04.2014).
[4] Altan, M.F., Kızıltaş, M.Ç., (2018), Toplu Taşımada Çok Amaçlı Karar Verme ve Metropolitan Bir Alanda Ev-İş Ulaşım Hizmeti Modellemesi, Karaelmas Fen ve Mühendislik Dergisi, ULAKBİM

[5] Kızıltaş M.Ç., (2014) 'Ulaştırma Yatırımları ve Marmaray-7',

http://www.ulastirmadunyasi.com/index.php/2013/12/ulast irma-yatirimlari-ve-marmaray-7/ (24.04.2014).

[6] Altan M.F., Kızıltaş M.Ç., (2019), Yüksek Hızlı Demiryolları, Yolcu Ve Yük Taşımacılığı Karşılaştırmaları Bağlamında Küresel Ölçekli Bir Derleme Çalışması, Dicle Üniversitesi Mühendislik Fakültesi Dergisi, ULAKBİM (yayın aşamasında)

[7] Kızıltaş M.Ç., (2014) 'Yüksek Hızlı Demiryolu Politikalar1-1', http://www.ulastirmadunyasi.com/?p=824 (01.10.2014).

[8] Romero, J.P., Moura, J.L., Ibeas, A., Benavente, J., (2012). Car-bicycle combined model for planning bicycle sharing systems. In: Transportation Research Board 91st Annual Meeting, Washington DC.

[9] Theurel, J., Theurel, A., Lepers, R., (2012). Physiological and cognitive responses when riding an electrically assisted bicycle versus a classical bicycle. Ergonomics 55, $773 \mathrm{e} 781$.

[10] Kızıltaş, M, Ç, 8-10 Kasım 2018, Küresel Örnekleri ile Toplu Ulaştırma, Transist 2018, İstanbul Ulaşım Kongresi ve Fuarı, İstanbul

[11] Asadi-Shekari, Z., Zaly-Shah, M., (2011). Practical evaluation method for pedestrian level of service in urban streets. In: International Transport Research Conference, Penang, Malaysia.

[12] Granado, F.J., Coady, D. and Gillingham, R., (2012). The Unequal Benefits of Fuel Subsidies: A Review of Evidence for Developing Countries, World Development Vol. 40, No. 11.

[13] Engel-Yan,J., Passmore, D., (2010).Assessing alternative approaches to setting parking requirements. ITE Journal $80,25-30$.

[14] Tzeng G., Shiau T., (1988) 'Multiple Objective Programming for Bus Operation: A Case Study for Taipei City, Transportation Research Part' B 22 (3), 195-206.

[15] Rawls J., (1971) 'A Theory of Justice', Harward University Press, Cambridge.

[16] İstanbul Büyükşsehir Belediyesi Ulaşım Dairesi Başkanlığı, (2012) İstanbul Ulaşım Ana Planı Hane Halkı Araştırması Raporu.

[17] Rawat D. B., (2016) Adaptive Connectivity, Security and Privacy in Transportation Cyber Physical Systems. Springer.

[18] T.C. Ulaştırma Denizcilik ve Haberleşme Bakanlığı, 2016

[19] Rawat D. B., Rodrigues J. J. and Stojmenovic I., (2015) Cyber-Physical Systems: From Theory to Practice. CRC Press.

[20] T.C. Karayolları Genel Müdürlüğü (KGM), 2015 